\title{
Enteric Pathogens and Reactive Arthritis: A Systematic Review of Campylobacter, Salmonella and Shigella-associated Reactive Arthritis
}

\author{
Anuli N. Ajene, Christa L. Fischer Walker, Robert E. Black \\ Department of International Health, Johns Hopkins Bloomberg School of Public Health, Baltimore, MD, USA
}

\begin{abstract}
Reactive arthritis (ReA) is a spondyloarthropathic disorder characterized by inflammation of the joints and tissues occurring after gastrointestinal or genitourinary infections. Diagnostic criteria for ReA do not exist and, therefore, it is subject to clinical opinion resulting in cases with a wide range of symptoms and definitions. Using standardized diagnostic criteria, we conducted a systematic literature review to establish the global incidence of ReA for each of the three most commonly-associated enteric pathogens: Campylobacter, Salmonella, and Shigella. The weighted mean incidence of reactive arthritis was 9, 12, and 12 cases per 1,000 cases of Campylobacter, Salmonella and Shigella infections respectively. To our knowledge, this is the first systematic review of worldwide data that use well-defined criteria to characterize diarrhoea-associated ReA. This information will aid in determining the burden of disease and act as a planning tool for public-health programmes.
\end{abstract}

Key words: Campylobacter; Enteric infections; Incidence; Reactive arthritis; Salmonella; Shigella

\section{INTRODUCTION}

Reactive arthritis (ReA), also known as postinfectious arthritisis, is a spondyloarthropathic disorder characterized by inflammation of the joints and tissues occurring after gastrointestinal or genitourinary infections (1-3). The most common enteric bacterial pathogens that have been implicated in ReA include Salmonella, Shigella, and Campylobacter (4).

There is no diagnostic test for ReA; it is based entirely on clinical characteristics and, thus, is subject to clinical opinion (5). In addition, there are no established criteria for ReA diagnosis. Therefore, cases include a wide range of symptoms and definitions, some of which resemble other spondyloarthropathic disorders $(1,5)$. A definite time period from infection to the onset of ReA has not been established which contributes to significant uncertainty and inconsistency between studies.

Correspondence and reprint requests:

Dr. Christa L. Fischer Walker

Department of International Health

Johns Hopkins Bloomberg School of Public Health 615 North Wolfe St., Room E5608

Baltimore, MD 21205

USA

Email: cfischer@jhsph.edu

Fax: 4109557159
This discordance has led to variability in incidence estimates for reactive arthritis $(1,3)$.

Since there is considerable inconsistency in the diagnosis of ReA, it is important to determine the burden of reactive arthritis due to enteric infections, using standard criteria. To our knowledge, this is the first systematic review of worldwide data that use well-defined criteria to establish the global incidence of ReA for each of the three most commonly-associated pathogens.

\section{MATERIALS AND METHODS}

We conducted a systematic literature review in Embase, PubMed, and Scopus databases, using all combinations of applicable MeSH and general terms for ReA, Campylobacter, Salmonella, and Shigella (Table 1a-1c). Additional articles were also retrieved from hand-searching reference lists of all articles selected for inclusion in the study. We sought to identify eligible case-control and prospective cohort studies that were published as of September 2011 in all languages. The inclusion criteria were laboratory confirmation of Campylobacter, Salmonella, or Shigella via stool or blood culture and ascertainment of ReA status within one year of infection. Prospective cohorts ascertained the clinical development of reactive arthritis via personal interview or chart 


\begin{tabular}{|c|c|c|c|}
\hline Table 1a & Embase & PubMed & Scopus \\
\hline $\begin{array}{l}\text { Campy- } \\
\text { lobacter }\end{array}$ & $\begin{array}{l}\text { 'reactive } \\
\text { arthritis'/exp } \\
\text { OR 'reactive } \\
\text { arthritis' AND } \\
\text { ('campy- } \\
\text { lobacter'/exp } \\
\text { OR 'campy- } \\
\text { lobacter') } \\
\text { AND [hu- } \\
\text { mans]/lim } \\
\text { AND [eng- } \\
\text { lish]/lim }\end{array}$ & $\begin{array}{l}\text { ("arthritis, reac- } \\
\text { tive" [MeSH } \\
\text { Terms] OR ("ar- } \\
\text { thritis" [All Fields] } \\
\text { AND "reactive" } \\
\text { [All Fields]) OR } \\
\text { "reactive arthritis" } \\
\text { [All Fields] OR ("re- } \\
\text { active" [All Fields] } \\
\text { AND "arthritis" } \\
\text { [All Fields])) AND } \\
\text { ("campylobacter" } \\
\text { [MeSH Terms] OR } \\
\text { "campylobacter" } \\
\text { [All Fields]) }\end{array}$ & $\begin{array}{l}\text { TITLE-ABS-KEY([40] OR \{Reactive Arthritides\} OR } \\
\text { \{Reactive Arthritis\} OR \{Post-Infectious Arthritis\} } \\
\text { OR \{Post Infectious Arthritis\} OR \{Postinfec- } \\
\text { tious Arthritis\} OR \{Arthritis Post-Infectious\} } \\
\text { OR \{Arthritides Post-Infectious\} OR \{Arthritis } \\
\text { Post Infectious\} OR \{Post-Infectious Arthritides\} } \\
\text { OR \{Arthritis Postinfectious\} OR \{Arthritides } \\
\text { Postinfectious\} OR \{Postinfectious Arthritides\} } \\
\text { OR \{Reiter Syndrome\} OR \{Syndrome Reiter\} } \\
\text { OR \{Reiter's Disease\} OR \{Disease Reiter's\} OR } \\
\text { \{Reiters Disease\} OR \{Reiter Disease\} OR \{Disease } \\
\text { Reiter\}) AND TITLE-ABS-KEY (\{campylobacter\} OR } \\
\text { \{Campylobacter coli\} OR \{Campylobacter fetus\} } \\
\text { OR \{Campylobacter hyointestinalis\} OR \{Campy- } \\
\text { lobacter jejuni\} OR \{Campylobacter lari\} OR } \\
\text { \{Campylobacter rectus\} OR \{Campylobacter spu- } \\
\text { torum\} OR \{Campylobacter upsaliensis\}) AND } \\
\text { (LIMIT-TO(LANGUAGE,"English")) }\end{array}$ \\
\hline Table $1 \mathrm{~b}$ & Embase & PubMed & Scopus \\
\hline Salmonella & $\begin{array}{l}\text { 'reactive } \\
\text { arthritis'/exp } \\
\text { OR 'reac- } \\
\text { tive arthritis' } \\
\text { AND ('salmo- } \\
\text { nella'/exp OR } \\
\text { 'salmonella') } \\
\text { AND [hu- } \\
\text { mans]/lim } \\
\text { AND [eng- } \\
\text { lish]/lim }\end{array}$ & $\begin{array}{l}\text { ("arthritis, reac- } \\
\text { tive" [MeSH } \\
\text { Terms] OR ("ar- } \\
\text { thritis" [All Fields] } \\
\text { AND "reactive"[All } \\
\text { Fields]) OR "reac- } \\
\text { tive arthritis" [All } \\
\text { Fields] OR ("reac- } \\
\text { tive" [All Fields] } \\
\text { AND "arthritis"[All } \\
\text { Fields])) AND ("sal- } \\
\text { monella" [MeSH } \\
\text { Terms] OR "salmo- } \\
\text { nella" [All Fields]) }\end{array}$ & $\begin{array}{l}\text { TITLE-ABS-KEY(\{Arthritides Reactive\} OR \{Re- } \\
\text { active Arthritides\} OR \{Reactive Arthritis\} OR } \\
\text { \{Post-Infectious Arthritis\} OR \{Post Infectious Ar- } \\
\text { thritis\} OR \{Postinfectious Arthritis\} OR \{Arthritis } \\
\text { Post-Infectious\} OR \{Arthritides Post-Infectious\} } \\
\text { OR \{Arthritis Post Infectious\} OR \{Post-Infectious } \\
\text { Arthritides\} OR \{Arthritis Postinfectious\} OR } \\
\text { \{Arthritides Postinfectious\} OR \{Postinfectious } \\
\text { Arthritides\} OR \{Reiter Syndrome\} OR \{Syndrome } \\
\text { Reiter\} OR \{Reiter's Disease\} OR \{Disease Reiter's\} } \\
\text { OR \{Reiters Disease\} OR \{Reiter Disease\} OR \{Dis- } \\
\text { ease Reiter\}) AND TITLE-ABS-KEY (\{Salmonella\} } \\
\text { OR \{Salmonella arizonae\} OR \{Salmonella en- } \\
\text { terica\} OR \{Salmonella enteritidis\} OR \{Salmonella } \\
\text { paratyphi A\} OR \{Salmonella paratyphi B\} OR } \\
\text { \{Salmonella paratyphi C\} OR \{Salmonella typhi\} } \\
\text { OR \{Salmonella typhimurium\}) AND (LIMIT-TO } \\
\text { (LANGUAGE,"English")) }\end{array}$ \\
\hline Table 1c & Embase & PubMed & Scopus \\
\hline Shigella & $\begin{array}{l}\text { 'reactive } \\
\text { arthritis'/exp } \\
\text { OR 'reactive } \\
\text { arthritis' AND } \\
\text { ('shigella'/exp } \\
\text { OR 'shigella') } \\
\text { AND [hu- } \\
\text { mans]/lim } \\
\text { AND [eng- } \\
\text { lish]/lim }\end{array}$ & $\begin{array}{l}\text { ("arthritis, reac- } \\
\text { tive" [MeSH } \\
\text { Terms] OR ("ar- } \\
\text { thritis" [All Fields] } \\
\text { AND "reactive" } \\
\text { [All Fields]) OR } \\
\text { "reactive arthritis" } \\
\text { [All Fields] OR ("re- } \\
\text { active" [All Fields] } \\
\text { AND "arthritis" } \\
\text { [All Fields])) AND } \\
\text { ("shigella" [MeSH } \\
\text { Terms] OR "shi- } \\
\text { gella" [All Fields]) }\end{array}$ & $\begin{array}{l}\text { TITLE-ABS-KEY(\{Arthritides Reactive\} OR \{Re- } \\
\text { active Arthritides\} OR \{Reactive Arthritis\} OR } \\
\text { \{Post-Infectious Arthritis\} OR \{Post Infectious Ar- } \\
\text { thritis\} OR \{Postinfectious Arthritis\} OR \{Arthritis } \\
\text { Post-Infectious\} OR \{Arthritides Post-Infectious\} } \\
\text { OR \{Arthritis Post Infectious\} OR \{Post-Infectious } \\
\text { Arthritides\} OR \{Arthritis Postinfectious\} OR } \\
\text { \{Arthritides Postinfectious\} OR \{Postinfectious } \\
\text { Arthritides\} OR \{Reiter Syndrome\} OR \{Syndrome } \\
\text { Reiter\} OR \{Reiter's Disease\} OR \{Disease Reiter's\} } \\
\text { OR \{Reiters Disease\} OR \{Reiter Disease\} OR } \\
\text { \{Disease Reiter\}) AND TITLE-ABS-KEY (\{shigella\} } \\
\text { OR \{shigella boydii\} OR \{shigella dysenteriae\} } \\
\text { OR \{shigella flexneri\} OR \{shigella sonnei\} AND } \\
\text { (LIMIT-TO(LANGUAGE,"English")) }\end{array}$ \\
\hline
\end{tabular}


reviews of individuals with laboratory-confirmed infections. For case-control studies, we searched for ones that tested for the presence of one of the selected ReA-triggering bacteria in both cases and controls. Cases had to be selected on the basis of ReA diagnosis with appropriate controls included.

We excluded studies that did not confirm the presence of gastrointestinal pathogens via laboratory methods, articles that did not specify the time lag between infection and the ascertainment of ReA, case reports, and review articles without original data. Articles with less than 15 subjects were also excluded. Full manuscripts were obtained for all eligible studies.

\section{Statistical methods}

We fit the data to a logistic regression model (6) to calculate a weighted mean for the incidence of ReA associated with gastroenteritis (7).

\section{RESULTS}

We identified 970 articles from Embase, PubMed, and Scopus databases that were screened for potential inclusion in the study (Figure). A total of thirtysix articles published between 1976 and 2010 met all inclusion criteria. These studies were conducted predominantly in Europe, with seven studies in
North America $(n=6)$ and Australia $(n=1)$. The time to ascertainment of ReA or development of symptoms ranged from within a month to 1 year postinfection, and the sample-size for cohort studies ranged from 37 to 57,425 . The results presented are based upon the pooled incidence rates only. Due to the lack of a standard definition of ReA, there was high heterogeneity between the studies (I-squared $>95 \%$ ); therefore, the meta-analysis model was not a good fit for the data. No case-control studies were identified; thus, it was not possible to calculate the background rate of ReA and the attributable rate of ReA due to enteric infections.

\section{Campylobacter}

We identified 25 articles for a full manuscript review. Out of these, 14 cohort studies (8-21) were included in the final assessment of the incidence of Campylobacter-associated reactive arthritis (Table 2). These cohort studies accounted for a total of 63,206 patients with Campylobacter infection, of which 573 progressed to reactive arthritis. The other 11 articles were excluded after reviewing the manuscripts due to either insufficient data on laboratory confirmation methods for all subjects, mixed bacterial isolates, information on time to ReA diagnosis missing or exceeding 12 months or they did not meet the other requirements for the study $(22,23)$. The

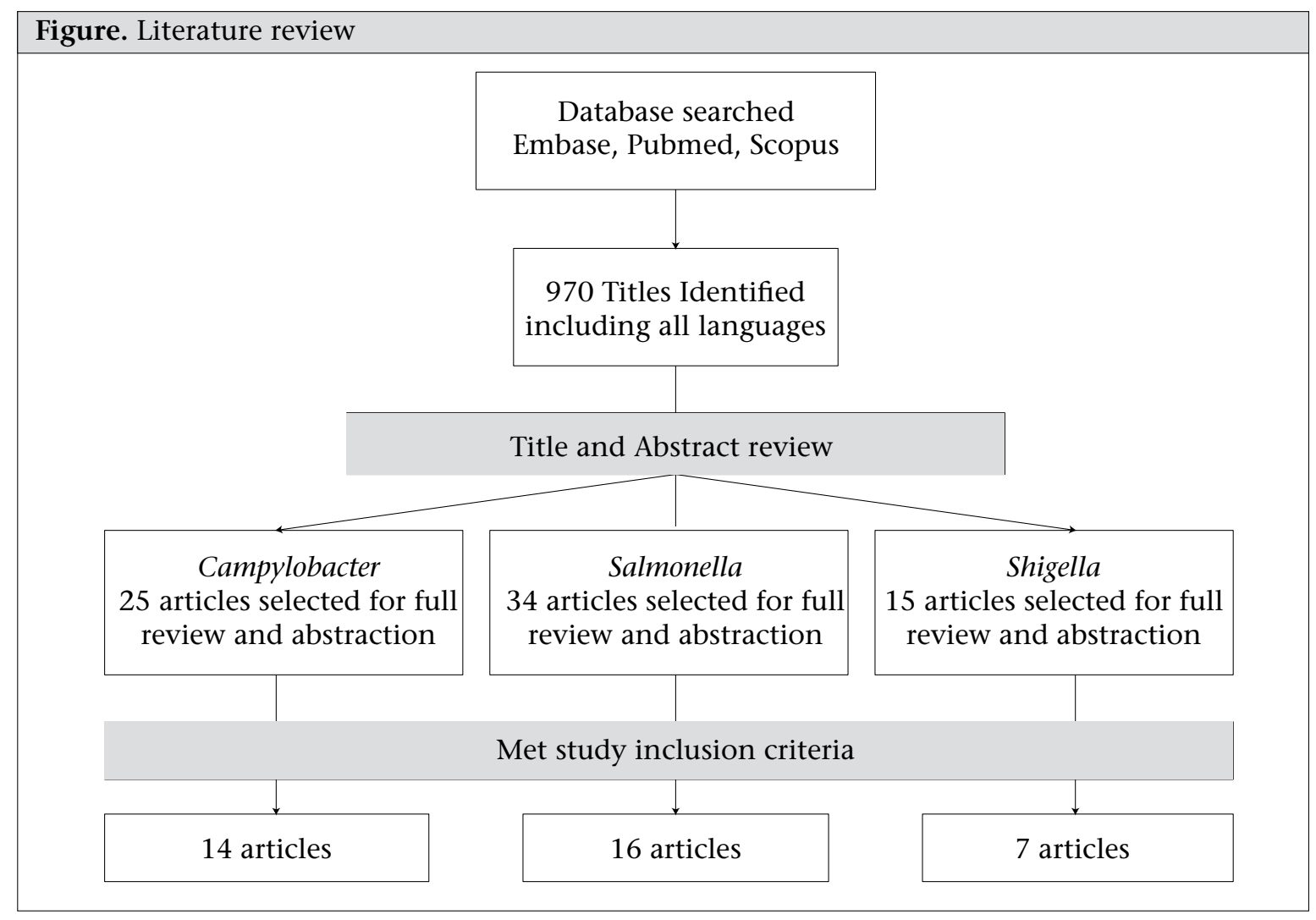




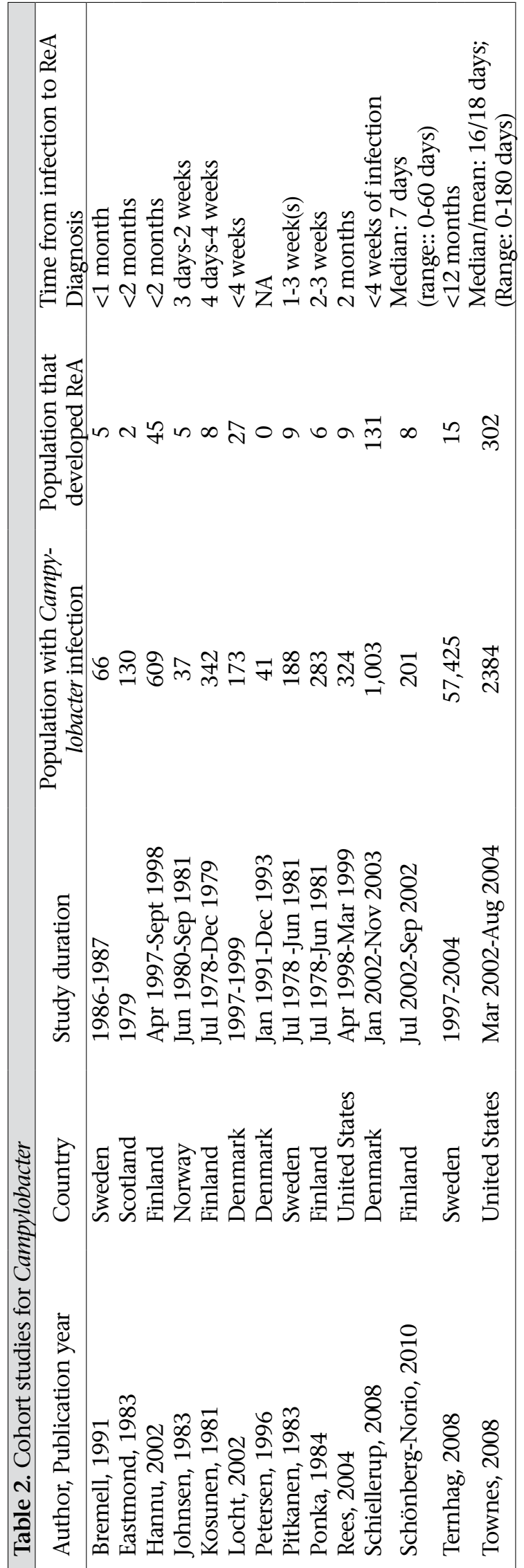

calculated pooled incidence rate was 0.009 (95\% CI 0.009-0.010). This is an incidence of 9 reactive arthritis cases per 1,000 cases of Campylobacter infection.

\section{Salmonella}

We identified 34 articles for a full manuscript review. Out of these, 16 cohort studies $(14,17,18,20,21,24$ 34 ) were included in the final assessment of the incidence of Salmonella-associated reactive arthritis (Table 3). These cohort studies accounted for a total of 39,148 patients with Salmonella infection, of which 474 progressed to reactive arthritis cases. Excluded articles did not contain relevant information or the time to ReA diagnosis was missing or exceeding 12 months, or data on laboratory confirmation methods for all subjects were insufficient. The calculated pooled incidence rate was 0.012 (95\% CI 0.011-0.013). This is an incidence of 12 reactive arthritis cases per 1,000 cases of Salmonella infection.

\section{Shigella}

We identified 15 articles for full manuscript review. Out of these, 7 cohort studies $(14,17,18,20,21,35,36)$ were included in the final assessment of the incidence of Shigella-induced reactive arthritis (Table 4). These studies accounted for a total of 4,636 patients with Shigella infection, of which 56 reactive arthritis cases were found. The seven articles were excluded due to insufficient information either on laboratory confirmation for all subjects or ReA status, or data on time to ReA diagnosis was missing. The calculated pooled incidence rate was 0.012 (95\% CI 0.009-0.015). This is an incidence of 12 reactive arthritis cases per 1,000 cases of Shigella infection.

\section{DISCUSSION}

We sought to characterize the incidence of ReA among cases of Campylobacter, Salmonella, and Shigella, using well-established criteria. Among the studies analyzed, ReA incidence ranged from 0-16\%, 0.1-29\%, and 0-12\% among Campylobacter, Salmonella and Shigella infections respectively. The weighted mean incidence was 9, 12, and 12 ReA cases per 1,000 Campylobacter, Salmonella and Shigella infections respectively.

It has been noted that gender does not play a role in enteric disease-associated ReA, and adults compared to children, are more susceptible to ReA following an enteric infection (3). In the present analysis, although only a small number of studies (Appendix) 


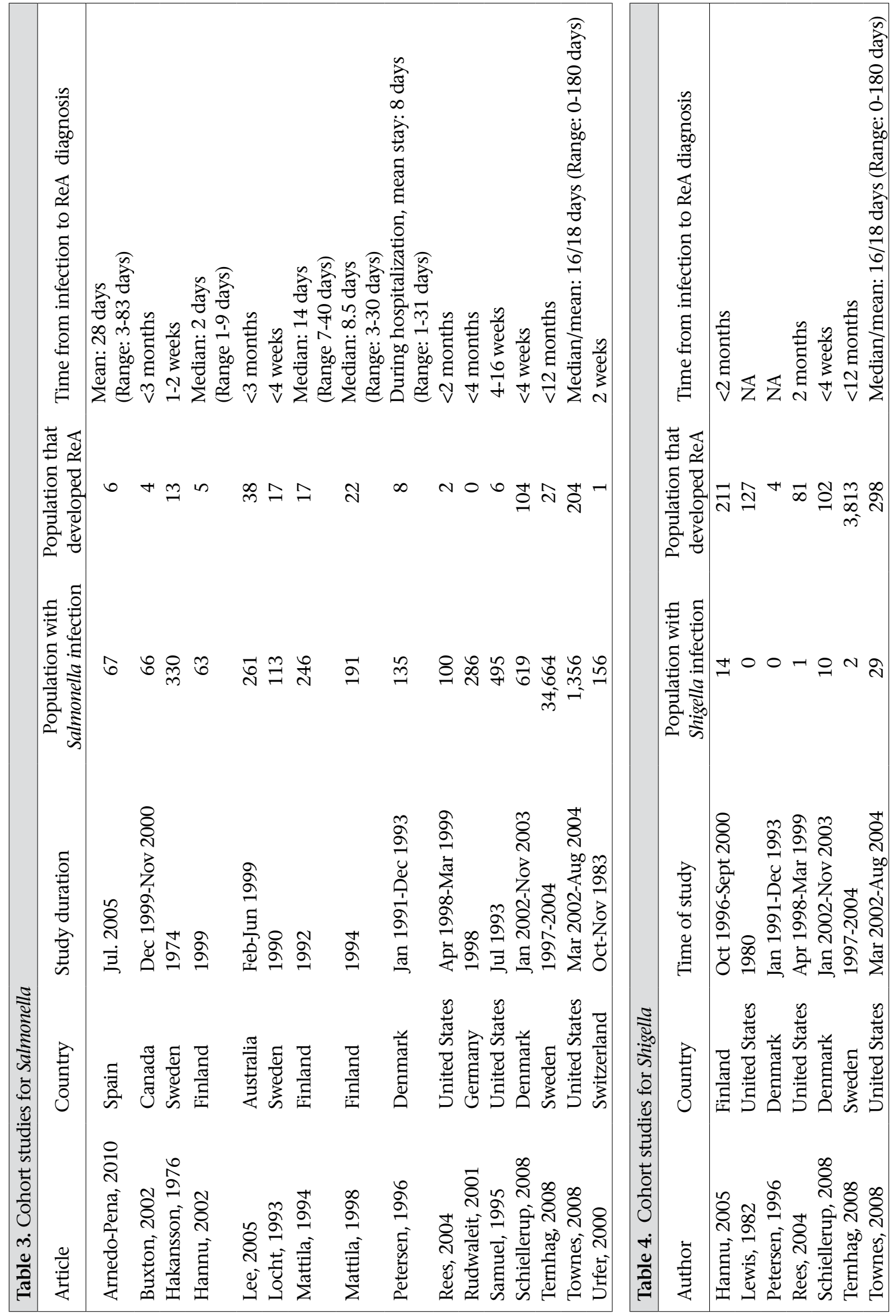


presented sufficient information to examine agerelated ReA, we found a similar trend. The incidence of Campylobacter-associated ReA ranged from $8 \%$ to $16 \%$ with a median of $8 \%$ among adults compared to $0 \%$ to $6 \%$ with a median of $3 \%$ among children. Salmonella-associated ReA ranged from $1 \%$ to $24 \%$ with a median of $11 \%$ among adults compared to $0 \%$ to $12 \%$ with a median of $5 \%$ among children. Shigella-associated ReA ranged from $7 \%$ to $12 \%$ with a median of $9.5 \%$ among adults compared to $0 \%$ to $7 \%$ with a median of $3.5 \%$ among children. Although the burden of enteric infections is higher among children aged $<5$ years (37), we found a lower incidence of reactive arthritis in children which could be due to the lack of full differentiation of their immune systems $(2,32)$. The information available on gender was insufficient to draw any conclusions.

Our incidence estimates are comparable to previous estimates $(3,18,32,35,38)$ but may underestimate ReA cases for several reasons. ReA is considered to be a condition that may undergo spontaneous resolution. Therefore, individuals with milder cases of disease may not report it (39). In hospital-based studies, all patients are typically followed with either medical chart reviews or interviews with patients to assess the development of ReA, thereby minimizing loss to follow-up. This is in contrast to population-based studies where only a proportion of individuals with enteric infections may be assessed for ReA. For instance, such studies included in this review mailed out surveys to individuals with confirmed enteric infections to assess ReA symptoms or status, and only a proportion ranging from $31 \%$ to $90 \%(n=12)$ returned completed surveys. Incidence estimates were only based upon the sample that returned surveys which could bias our results in either direction if there was a differential response in those who developed ReA. We performed further subanalyses, which excluded any study that had less than $70 \%$ of the subjects returning surveys $(n=6)$, and the incidence estimates changed slightly with rates of 0.009 (95\% CI 0.008-0.010) for Campylobacter, 0.011 (95\% CI 0.010-0.012) for Salmonella, and 0.012 (95\% CI 0.009-0.016) for Shigella.

Additionally, ReA is known to be a sequela of asymptomatic enteric infections $(2,40)$. In this review, the ReA incidence estimates were based upon laboratory-confirmed cases of infection and may have missed those cases of ReA with negative laboratory findings or asymptomatic presentations, thereby leading to an under-estimation of the incidence.
However, in the absence of a well-designed epidemiological study or population-wide screening, it would be difficult to ascertain the exact incidence of ReA in both symptomatic and asymptomatic cases.

Pope and colleagues (41) performed a review of Campylobacter-associated ReA and found an incidence of $1-5 \%$. However, this review did not establish any inclusion or exclusion criteria, and a distinction was made between acute and chronic ReA. The authors noted that cases of ReA varied considerably due to limitations in case assessment and diagnostics for ReA. This review suggested that young adults were more commonly affected by ReA. Genetics, specifically the presence of human leukocyte antigen (HLA)-B27, was found to have a mixed association with ReA. There is considerable discussion regarding HLA-B27 and its role in ReA $(1,42)$, and it is suggested that HLA-B27-positive individuals may have an increased susceptibility to ReA (43). However, the data on the association between HLA-B27 and ReA are conflicting with other studies finding no association $(10,21)$.

We believe our review improves upon estimate of Pope and colleagues by imposing a timeframe for ReA case ascertainment, i.e. within a year of infection, and utilizing inclusion/exclusion criteria to increase uniformity among the estimates for the three enteric infections. These criteria assist in addressing the major limitation in estimating incidence for ReA, i.e. the lack of diagnostic criteria. Time to ascertainment of ReA was based upon the majority of studies that assessed ReA within one year post-enteric infection. Defining time to ReA can play an important role in the incidence estimates, for instance, one study that initially assessed ReA status among individuals with enteric infections found no cases within 3 months of infection. However, a re-assessment 1 year later in the same population discovered incident ReA cases (20). This indicates a potential for the number of ReA cases to be under-estimated, especially among studies with shorter timeframes.

We did not assess the role of treatment of enteric infections on the development of ReA as the data were sparse concerning the patients who received treatment. It has, however, been suggested that incidence of ReA is lower where prompt treatment is available (44). The data in this area are also limited and inconsistent with a randomized clinical trial (45) finding no association between antibiotic treatment and improved arthritis outcomes. 
We present the incidence of ReA as sequelae of Campylobacter, Salmonella and Shigella infections, using worldwide data. We conducted a thorough search and used strict inclusion and exclusion criteria; yet, even with this method, we acknowledge that these estimates will have limitations until better diagnostic criteria become available. This includes stricter criteria for appropriate time intervals between infection and symptoms of ReA as well as standardized tests to detect bacterial antigens.

ReA remains an important consequence of gastrointestinal infections. These infections due to foodborne pathogens have been estimated to afflict up to $30 \%$ of the population in developed countries, with much higher attack rates in the developing world (46). With incidence rates between 1 and $2 \%$, ReA affects a significant number of individuals worldwide, especially in countries that have high rates of food- and water-borne infections. Although ReA can be self-limiting, resolving within 6 months, it has been estimated that up to $63 \%$ of afflicted persons will develop a chronic form of ReA (3). This not only increases morbidity, it imposes an additional socioeconomic burden on individuals and societies. This highlights the need for early diagnosis of disease, prompt and effective treatment, and prevention of enteric infections. Improved estimates on the global incidence of ReA would serve as a tool in the development of appropriate publichealth prevention programmes.

\section{ACKNOWLEDGEMENTS}

The authors would like to thank Jamie Perin (JH$\mathrm{SPH})$ for her assistance in statistical analysis.

\section{REFERENCES}

1. Townes JM. Reactive arthritis after enteric infections in the United States: the problem of definition. Clin Infect Dis 2010;50:247-54.

2. Carter JD, Hudson AP. Reactive arthritis: clinical aspects and medical management. Rheum Dis Clin North Am 2009;35:21-44.

3. Carter JD. Reactive arthritis: defined etiologies, emerging pathophysiology, and unresolved treatment. Infect Dis Clin North Am 2006;20:827-47.

4. Wu IB, Schwartz RA. Reiter's syndrome: the classic triad and more. J Am Acad Dermatol 2008;59:11321.

5. Sieper J, Rudwaleit M, Braun J, van der Heijde D. Diagnosing reactive arthritis: role of clinical setting in the value of serologic and microbiologic assays. $A r$ thritis Rheum 2002;46:319-27.
6. Greenland S. Interpretation and choice of effect measures in epidemiologic analyses. Am J Epidemiol 1987;125:761-8.

7. Borenstein M, Hedges LV, Higgins JPT, Rothstein HR. Introduction to meta-analysis. Chichester, WS: Wiley, 2009. $450 \mathrm{p}$.

8. Bremell T, Bjelle A, Svedhem A. Rheumatic symptoms following an outbreak of Campylobacter enteritis: a five year follow up. Ann Rheum Dis 1991;50:934-8.

9. Eastmond CJ, Rennie JA, Reid TM. An outbreak of Campylobacter enteritis-a rheumatological followup survey. J Rheumatol 1983;10:107-8.

10. Hannu T, Mattila L, Rautelin H, Pelkonen P, Lahdenne P, Siitonen A et al. Campylobacter-triggered reactive arthritis: a population-based study. Rheumatology (Oxford) 2002;41:312-8.

11. Johnsen K, Ostensen M, Melbye AC, Melby K. HLAB27-negative arthritis related to Campylobacter jejuni enteritis in three children and two adults. Acta Med Scand 1983;214:165-8.

12. Kosunen TU, Pönkä A, Kauranen O, Martio J, Pitkänen T, Hortling L et al. Arthritis associated with Campylobacter jejuni enteritis. Scand J Rheumatol 1981;10:7780.

13. Locht H, Krogfelt KA. Comparison of rheumatological and gastrointestinal symptoms after infection with Campylobacter jejuni/coli and enterotoxigenic Escherichia coli. Ann Rheum Dis 2002;61:448-52.

14. Petersen AM, Nielsen SV, Meyer D, Ganer P, Ladefoged K. Bacterial gastroenteritis among hospitalized patients in a Danish County, 1991-93. Scand J Gastroenterol 1996;31:906-11.

15. Pitkänen T, Pönkä A, Pettersson T, Kosunen TU. Campylobacter enteritis in 188 hospitalized patients. Arch Intern Med 1983;143:215-9.

16. Pönkä A, Pitkänen T, Sarna S, Kosunen TU. Infection due to Campylobacter jejuni: a report of 524 outpatients. Infection 1984;12:175-8.

17. Rees JR, Pannier MA, McNees A, Shallow S, Angulo FJ, Vugia DJ. Persistent diarrhea, arthritis, and other complications of enteric infections: a pilot survey based on California FoodNet surveillance, 19981999. Clin Infect Dis 2004;38(Suppl 3):S311-7.

18. Schiellerup P, Krogfelt KA, Locht H. A comparison of self-reported joint symptoms following infection with different enteric pathogens: effect of HLA-B27. J Rheumatol 2008;35:480-7.

19. Schönberg-Norio D, Mattila L, Lauhio A, Katila ML, Kaukoranta SS, Koskela M et al. Patient-reported complications associated with Campylobacter jejuni infection. Epidemiol Infect 2010;138:1004-11.

20. Ternhag A, Törner A, Svensson Å, Ekdahl K, Giesecke 
J. Short- and long-term effects of bacterial gastrointestinal infections. Emerg Infect Dis 2008;14:143-8.

21. Townes JM, Deodhar AA, Laine ES, Smith K, Krug $\mathrm{HE}$, Barkhuizen A et al. Reactive arthritis following culture-confirmed infections with bacterial enteric pathogens in Minnesota and Oregon: a populationbased study. Ann Rheum Dis 2008;67:1689-96.

22. Ruzante JM, Majowicz SE, Fazil A, Davidson VJ. Hospitalization and deaths for select enteric illnesses and associated sequelae in Canada, 2001-2004. Epidemiol Infect 2011;139:937-45.

23. Söderlin MK, Kautiainen H, Puolakkainen M, Hedman K, Söderlund-Venermo M, Skogh T et al. Infections preceding early arthritis in southern Sweden: a prospective population-based study. I Rheumatol 2003;30:459-64.

24. Arnedo-Pena A, Beltrán-Fabregat J, Vila-Pastor B, Tirado-Balaguer $\mathrm{MD}$, Herrero-Carot $\mathrm{C}$, Bellido-Blasco $\mathrm{JB}$ et al. Reactive arthritis and other musculoskeletal sequelae following an outbreak of Salmonella hadar in Castellon, Spain. J Rheumatol 2010;37:1735-42.

25. Buxton JA, Fyfe M, Berger S, Cox MB, Northcott KA; Multiprovincial Salmonella typhimurium CaseControl Study Group. Reactive arthritis and other sequelae following sporadic Salmonella typhimurium infection in British Columbia, Canada: a case control study. J Rheumatol 2002;29:2154-8.

26. Håkansson U, Eitrem R, Löw B, Winblad S. HLA-antigen b27 in cases with joint affections in an outbreak of salmonellosis. Scand J Infect Dis 1976;8:245-8.

27. Hannu T, Mattila L, Siitonen A, Leirisalo-Repo M. Reactive arthritis following an outbreak of Salmonella typhimurium phage type 193 infection. Ann Rheum Dis 2002;61:264-6.

28. Lee AT, Hall RG, Pile KD. Reactive joint symptoms following an outbreak of Salmonella typhimurium phage type 135a. J Rheumatol 2005;32:524-7.

29. Locht H, Kihlström E, Lindström FD. Reactive arthritis after Salmonella among medical doctors-study of an outbreak. J Rheumatol 1993;20:845-8.

30. Mattila L, Leirisalo-Repo M, Koskimies S, Granfors K, Siitonen A. Reactive arthritis following an outbreak of Salmonella infection in Finland. Br J Rheumatol 1994;33:1136-41.

31. Mattila L, Leirisalo-Repo M, Pelkonen P, Koskimies S, Granfors K, Siitonen A. Reactive arthritis following an outbreak of Salmonella Bovismorbificans infection. J Infect 1998;36:289-95.

32. Rudwaleit M, Richter S, Braun J, Sieper J. Low incidence of reactive arthritis in children following a Salmonella outbreak. Ann Rheum Dis 2001;60:1055-7.
33. Samuel MP, Zwillich SH, Thomson GT, Alfa M, Orr $\mathrm{KB}$, Brittain DC et al. Fast food arthritis-a clinicopathologic study of post-Salmonella reactive arthritis. J Rheumatol 1995;22:1947-52.

34. Urfer E, Rossier P, Méan F, Krending M-J, Burnens A, Bille J et al. Outbreak of Salmonella braenderup gastroenteritis due to contaminated meat pies: clinical and molecular epidemiology. Clin Microbiol Infect 2000;6:536-42.

35. Hannu T, Mattila L, Siitonen A, Leirisalo-Repo M. Reactive arthritis attributable to Shigella infection: a clinical and epidemiological nationwide study. Ann Rheum Dis 2005;64:594-8.

36. Lewis RB. The absence of reactive arthritis after Shigella sonnei infection. Arthritis Rheum 1982;25:1267.

37. Centers for Disease Control. Incidence and trends of foodborne illness, 2011. 2011. (http://www.cdc.gov/ features/dsfoodnet/, accessed on 1 February 2013).

38. Ang CW, Krogfelt K, Herbrink P, Keijser J, van Pelt W, Dalby $\mathrm{T}$ et al. Validation of an ELISA for the diagnosis of recent Campylobacter infections in Guillain-Barré and reactive arthritis patients. Clin Microbiol Infect 2007;13:915-22.

39. Clegg DO, Reda DJ, Weisman MH, Cush JJ, Vasey FB, Schumacher HR, Jr. et al. Comparison of sulfasalazine and placebo in the treatment of reactive arthritis (Reiter's syndrome). A Department of Veterans Affairs Cooperative Study. Arthritis Rheum 1996;39:2021-7.

40. Hannu T, Inman R, Granfors K, Leirisalo-Repo M. Reactive arthritis or post-infectious arthritis? Best Pract Res Clin Rheumatol 2006;20:419-33.

41. Pope JE, Krizova A, Garg AX, Thiessen-Philbrook H, Ouimet JM. Campylobacter reactive arthritis: a systematic review. Semin Arthritis Rheum 2007;37:48-55.

42. Yu D, Kuipers JG. Role of bacteria and HLA-B27 in the pathogenesis of reactive arthritis. Rheum Dis Clin North Am 2003;29:21-36.

43. Ekman P, Kirveskari J, Granfors K. Modification of disease outcome in Salmonella-infected patients by HLA-B27. Arthritis Rheum 2000;43:1527-34.

44. Long-term antibiotic treatment in reactive arthritis. Lancet 1988;1:245-6.

45. Frydén A, Bengtsson A, Foberg U, Svenungsson B, Castor B, Kärnell A et al. Early antibiotic treatment of reactive arthritis associated with enteric infections: clinical and serological study. BMJ 1990;301:1299-302.

46. World Health Organization. Food safety and foodborne illness. 2007. (http://foodhygiene2010.files. wordpress.com/2010/06/who-food_safety_factsheet.pdf, accessed on 26 July 2011). 


\begin{tabular}{|llcc|}
\hline Appendix. Age-related incidence of reactive arthritis & Adult incidence of \\
Bacteria & Author & 8 & $\begin{array}{c}\text { Child incidence of } \\
\text { ReA (\%) }\end{array}$ \\
\hline Campylobacter & Bremell, 1991 & 8 & 0 \\
& Eastmond, 1983 & 16 & 6 \\
& Hannu, 2002 & 4 & - \\
& Johnsen, 1983 & 15 & - \\
Kalmonella & Kosunen, 1981 & 12 & - \\
& Hannu, 2002 & 9 & 0 \\
& Lee, 2005 & 1 & 7 \\
Shigella & Locht, 1993 & - & 0 \\
& Mattila, 1994 & 7 & 0 \\
\hline
\end{tabular}

